\title{
X-linked Spondyloepiphyseal Dysplasia Tarda: Clinical and Linkage Data
}

\author{
R. M. BANNERMAN, G. B. INGALL, and J. F. MOHN \\ From the Medical Genetics Unit, Department of Medicine and the Blood Group Research Unit, Department of \\ Microbiology State University of New York at Buffalo, Buffalo, New York, USA
}

The syndrome of short stature inherited as an $\mathrm{X}$-linked recessive trait was first reported by Jacobsen (1939) who described one family under the title 'hereditary osteochondrodystrophia deformans'. Three more pedigrees were studied by Maroteaux, Lamy, and Bernard (1957), who proposed the name dysplasia spondyloepiphysaire tardive, or spondyloepiphyseal dysplasia tarda (SDT). These authors also drew attention to earlier description by Nilsonne (1927) and Volhard and von Drigalski (1937) of two sibships, each with three affected brothers. Other pedigrees have been reported by Barber (1960) and Langer (1964), and Hobaek's monograph (1961) includes at least one pedigree (family 13) which appears to fit the criteria for this syndrome. These may be listed as follows:

(1) X-linked recessive inheritance. (2) Short stature first evident in childhood between 5-14 years. (3) Shortness due to impaired growth of spine. (4) Radiologically, characteristic flattening of vertebrae with central humping. (5) Dysplastic changes of femoral heads and neck. (6) Minor changes in other bones.

We have had the opportunity to restudy the family described by Jacobsen and to re-examine several of his patients more than 25 years later. We report here the revised and extended pedigree, clinical and radiological findings in affected males and in carriers, and the results of a linkage study of SDT and $\mathrm{Xg}^{\mathrm{a}}$ in this predigree. Preliminary results have been presented by Bannerman, Ingall, and Mohn (1966a and b) and Bannerman (1969).

Blood Grouping. Blood specimens were collected by venepuncture into sterile, screw-cap tubes without anticoagulant and were usually brought to the Blood Group Research Unit on the same day. Occasionally they had to be transported by air from

Received 16 February 1971. distant parts of the country. On some of these two separate samples were tested with no discrepancies in the results.

The $\mathrm{Xg}^{\mathrm{a}}$ blood groups were determined with a single example of anti- $\mathrm{Xg}^{\mathrm{a}}$ serum detectable only by the indirect antiglobulin technique with selected anti-human globulin sera (rabbit).

Colour Blindness. Tests were carried out by means of the Isihara plates (editions of 1960 and 1964) using bright daylight with rare exceptions.

The Family. This large and far-flung family, of English origin, has been settled for several generations in North Carolina where many members were visited in their homes. Others had moved to Buffalo, New York and were studied there, and some were seen when they visited Buffalo. Most members of the family have cooperated enthusiastically in the study and are aware that the condition is hereditary. The propositus, J.L. (V.37), who was first seen by Jacobsen when he suffered an acute episode of back pain at the age of 15, was reexamined in the present investigation at the age of 44. The latest revision of the pedigree is set out in Fig. 1, and further details are included in Table I and in the following individual case reports.

\section{Case Reports}

III.5 (J.B.) is known to have been affected, by history, and from Jacobsen's report (1939) in which he is case 4. Kyphosis began in childhood and became more pronounced until early manhood. He subsequently suffered increasing rigidity of the back and hips but had led a normal, active life. Radiological findings are described by Jacobsen (1939) and included characteristic changes in the spine and marked osteoarthritis of the hips. We do not know his subsequent history in detail, but he died at home aged 71 .

IV.6 (H.M.) aged 67 was the oldest patient seen by us. He was uncertain when his short stature had first been 


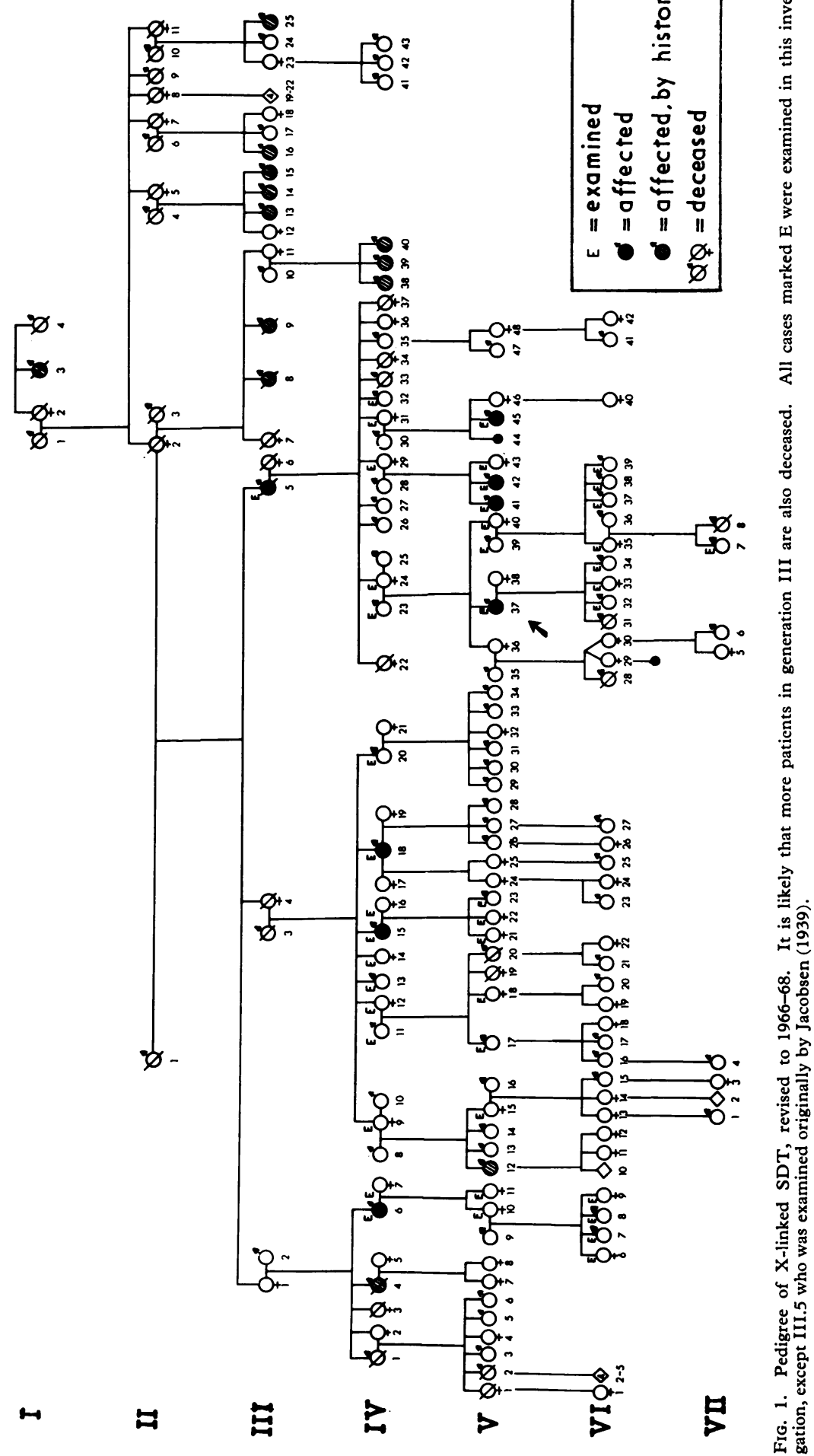




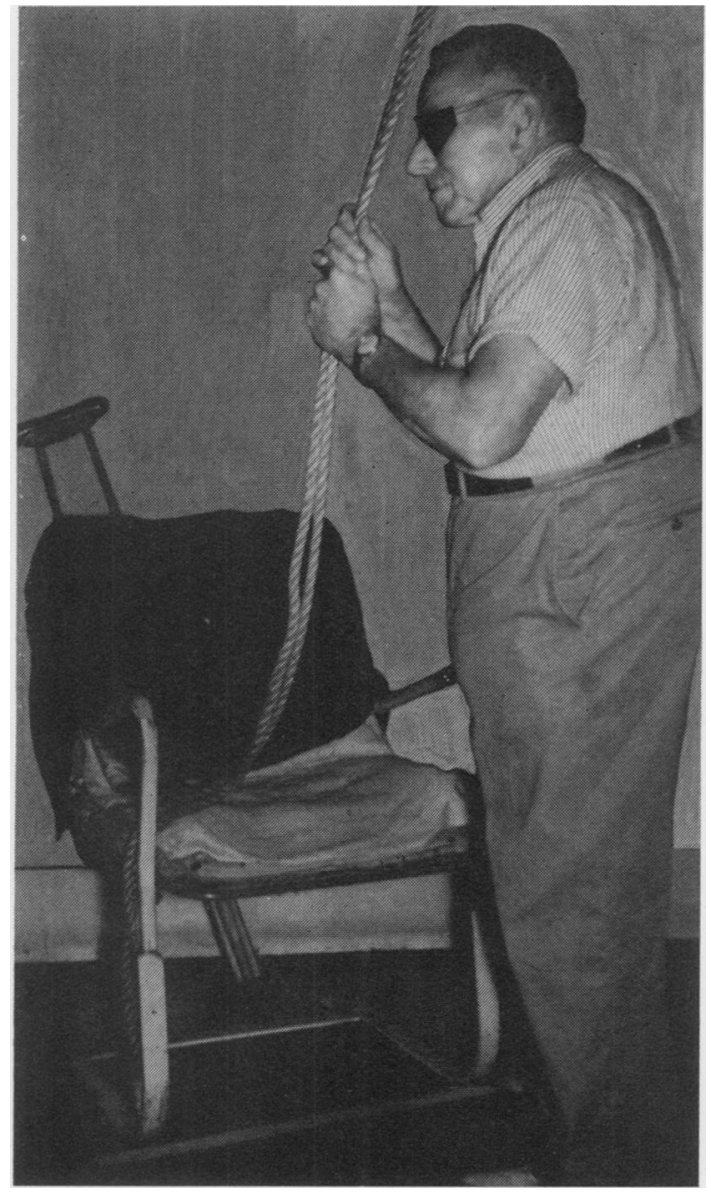

FIG. 2. Affected male (IV.6), aged 67. Because of rigidity of spine and hips the patient used a rope hung from the ceiling to swing himself in and out of a chair and from room to room.

noticeable, but himself dated it to an accident with a wagon at the age of 8 to 10 after which he failed to grow. However, he had been able to work in a cotton mill until he was aged 34 . From then on he had recurrent episodes of arthritis of the feet and hips. At the age of 50 an operation was carried out on his right hip. In recent years, he had become increasingly stiff and troubled by pain in the spine and hips, so that he had been unable to leave the house and was unable to get into a car. On inspection, the short neck and forward protrusion of the chest were striking. The spine and hips seemed to be completely stiff, so that the patient moved and sat in one piece. He was able to work his way around two rooms of his house by means of a rope attached to the ceiling (Fig. 2). Unfortunately, testing for colour blindness was ambiguous because of cataracts, although some responses suggested that he might be colour blind.
IV.15 (W.S.) the affected cousin of the previous patient, was seen at the age of 63, in his home. He grew up on a farm and had worked in a cotton mill and as a barber. Pain in the back had first begun when he was 25 , and he had to stop working because of it in his forties. $\mathrm{He}$ had complained of paraesthesias in the hands and 'jerks' in the legs, suggesting some cervical cord involvement, but full clinical examination was not practicable. However, he showed the characteristic short stature, with short neck, chest-expanded in the anteroposterior diameter, and had marked arthritis of the hips.

IV.18 (P.S.) was seen at the age of 40 at his home. He stated that he had always been short, but had worked as a mechanic until 10 years previously, when he was forced to stop working because of severe pain in the hips. On brief examination, he was a lively little man, much resembling the propositus, J.L., his cousin. He had a very short neck, a prominent chest, stiff spine, and walked with a rolling limp. No radiological data was available, but there was no difficulty in classifying him as affected. He had two daughters and three sons by two marriages; neither of his two grandsons by his daughters is known to be affected.

IV.24 (Mrs M.Z.) is the daughter of an affected male (III.V) and the mother of our propositus (J.L., V.37). She had a long history of arthritis since age 33 when she was treated in the Massachusetts General Hospital with immobilization for 'rheumatoid arthritis', but the original records could not be traced. She was an inpatient of the Buffalo General Hospital at the age of 51, when both hips were almost without movement and on $x$-ray the left hip showed solid bony fusion. There was partial bony fusion of the sacro-iliac joints. A cup arthroplasty of the right hip was performed. On a subsequent admission, one year later, the right hip was manipulated under anaesthesia. On re-examination by us at age 66 , abnormal findings were confined to the joints. There was limitation of movement of the lower cervical spine. The left hip was fixed and there was limited movement of the right. There was slight limitation of movement of the right wrist and some angulation of the distal phalanges in several fingers. Heberden's nodes were present. Radiology confirmed bony fusion of the left hip, a cup arthroplasty in the right hip, complete fusion of both sacro-iliac joints and ill-defined apophyseal joints of the lumbar vertebrae. The dorsal vertebrae did not show any gross abnormality. There was complete fusion of the apophyseal joints of the lower cervical vertebrae. $X$-rays of the feet were normal. $X$-rays of the hands showed osteoarthritic changes with narrowing of the joint space and cystic subarticular bone absorption in the terminal interphalangeal joints on the left. Despite limitation of hip movement, this patient leads an active life and supports herself as a seamstress.

IV.29 (Mrs V.P.) also the daughter of an affected male (III.5) and the mother of two affected males (V.41 and V.42) had no significant complaints relating to bones and joints and was normal on examination at the age of 58 


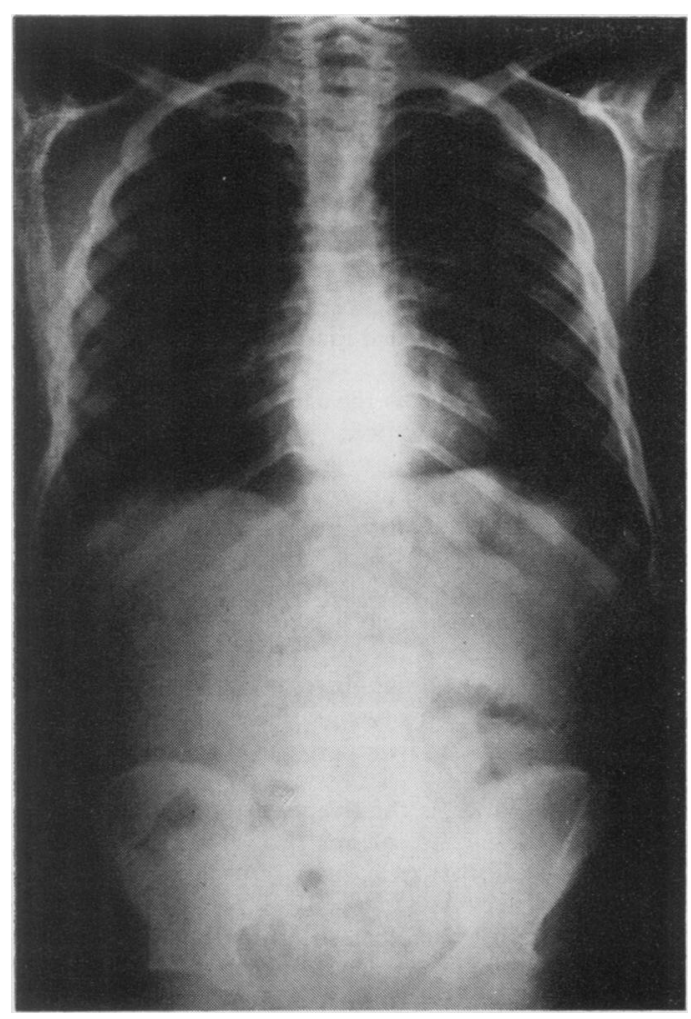

Fig. 3. The propositus V.37 aged 15: $x$-ray showing the broad chest overhanging the abdomen and narrow pelvis.

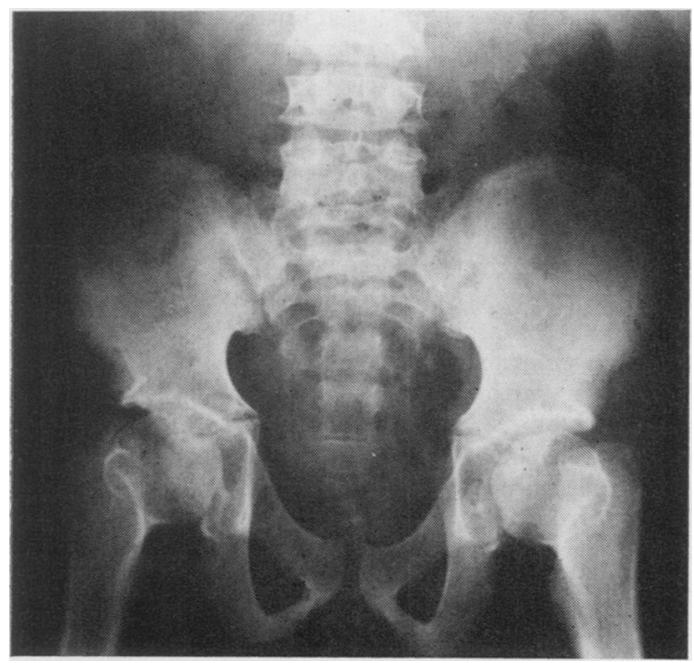

Fig. 4. The propositus V.37 aged 15: $x$-ray of pelvis and hips showing narrow pelvis and dysplastic changes in the acetabulae and femoral heads.

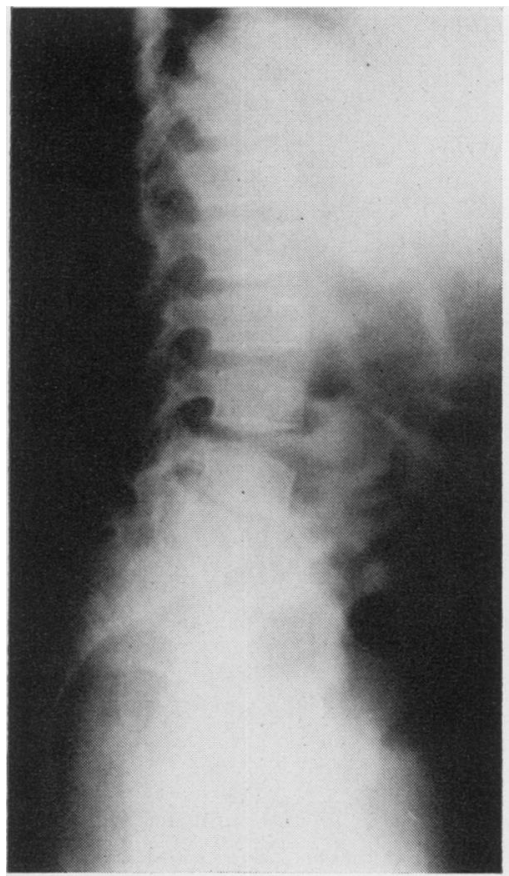

FIG. 5a

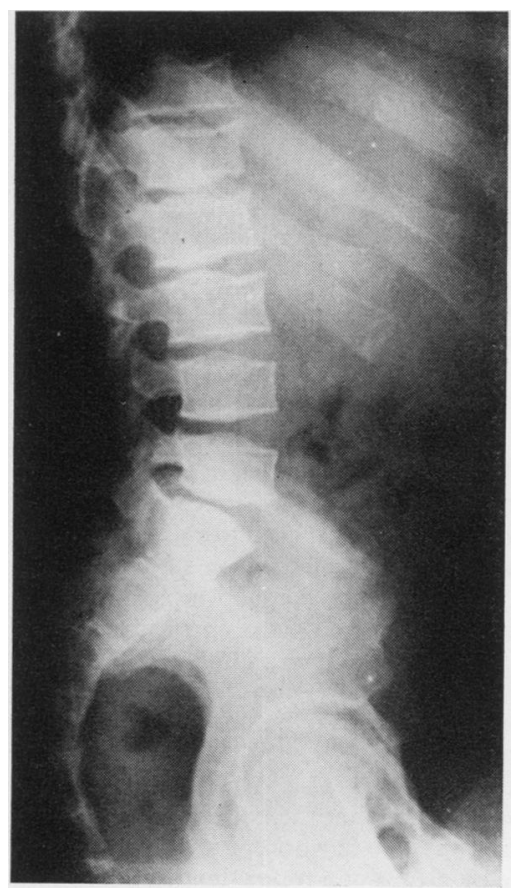

Fig. 5b

Fig. 5. Lateral $x$-rays of the lumbar spine in the propositus (V.37) aged 16 (Fig. 5a) and aged 17 (Fig. 5b). 
except for an exaggeration of the lumbar lordosis. She was 62 inches in height. All joints moved freely. Radiology of the spine, pelvis, and hip joints was normal.

IV.31 (Mrs B.B.) also the daughter of one affected male (III.5) and the mother of another (V.45) had no recent complaints except for slight backache. Apart from scars of cholecystectomy and Caesarean section no clinical abnormalities were found. Radiology of spine, pelvis, and hips was normal. Both this patient's children (C.B. V.45 and P.B. V.46) have congenital deafness but there is no other history of deafness in the family.

V.37 (J.L.) our propositus and also the propositus in Jacobsen's investigation, was aged 44 at the time of this study. His parents had noted in childhood that his body was not growing in the normal way, that his shoulders seemed to be held abnormally high, that his neck appeared shorter, and that his chest seemed to increase in size out of proportion to the rest of his body. However, he was healthy and active until the age of 15 years when he collapsed with severe back pain and was admitted to the Children's Hospital of Buffalo. It was noted then that his neck was very short and that there was marked kyphosis and pigeon breast with short trunk. At that time radiology showed the classic appearance of flattening and broadening of the vertebral bodies (illusstrated by Jacobsen, 1939). Figure 3 shows how the broad chest overhung and appeared to encroach on the abdomen. There were dysplastic changes in the hip joints also (Fig. 4). Investigation was otherwise negative. The patient was treated by the use of a Bradford frame for 12 months after which he gradually began to walk with crutches without pain. Two years after this admission his spine was rigid and free from pain and he walked without difficulty (Jacobsen, 1939). Further $x$-rays of the spine showed the characteristic appearance (Fig. 5a and b).

In subsequent years he lived a very active life, successfully running his own business and piloting a private aeroplane. When re-examined at age 44 , he had no spontaneous complaints but noted limitation in movement of the hips and shoulders and occasional pain in the hips and left shoulder. $\mathrm{He}$ was conscious of slight shortness of breath. Examination showed a short man (height, $52 \frac{1}{2}$ inches) with an especially short trunk and marked anterior protrusion of the sternum. There was no kyphosis but rather the spine was straight and rigid, with extra skin folds in the lumbar region. There was slight flexion deformity of the distal interphalangeal joints.

The propositus' three surviving children, aged 16, 15, and 12 were all healthy, and all over 60 inches in height. The eldest (VI.31) had been killed, aged 17, in a motor accident.

V.41 (W.P.) was first seen at $7 \frac{1}{2}$ years of age when the diagnosis was made by Jacobsen (1939, case 2 ). At this time he had complained of pain in legs and back for about two years. He was found to have a protruberant abdomen, marked lordosis and slight scoliosis. Radio- logy showed vertebral changes; the vertebrae, particularly from the 7th dorsal to the first lumbar appearing nearly ovoid in lateral projection. Minor abnormalities of the sacroiliac joints and of the acetabula and femoral heads, 'mixed cystic and sclerotic changes', were also described.

He was not seen again by us, but $x$-rays and a blood sample for blood grouping tests were obtained by mail with the help of his own physician in California, when the patient was aged 37. Although recent medical history was not available to us, it is of great interest that the lumbar and lower dorsal spine already show marked calcification of the intervertebral disc regions (Fig. 6). The hips showed moderate dysplastic changes (Fig. 7).

V.42 (J.P.) the only brother of V.41, was also seen in childhood, aged $3 \frac{1}{2}$, by Jacobsen (1939, case 3$)$, who remarked that the minor physical finding of lordosis would easily have been overlooked had the family history not been known. However, even at this age, changes were detectable in $x$-rays of the dorsal spine and there was slight condensation of the acetebular roof.

He was seen by us when he was 33 . He had been aware that he stopped growing in height at about the time of adolescence, but he had suffered no disability.

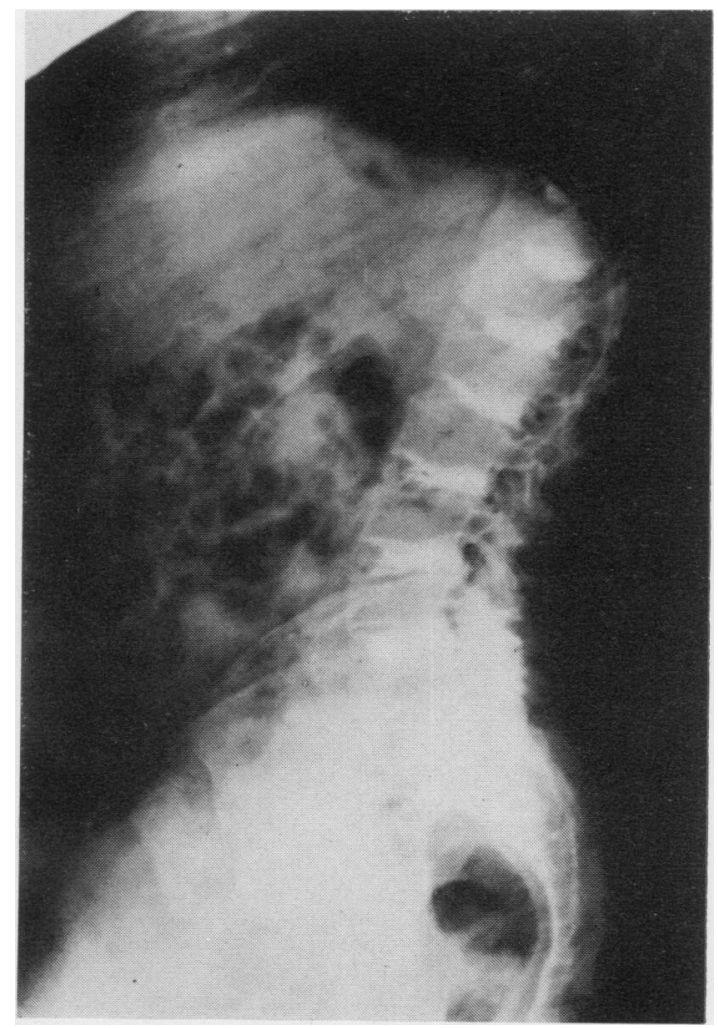

FIG. 6. Lateral $x$-ray of lumbar spine in an affected male (V.41) aged 37 , showing the presence of intervertebral calcification at this age. 


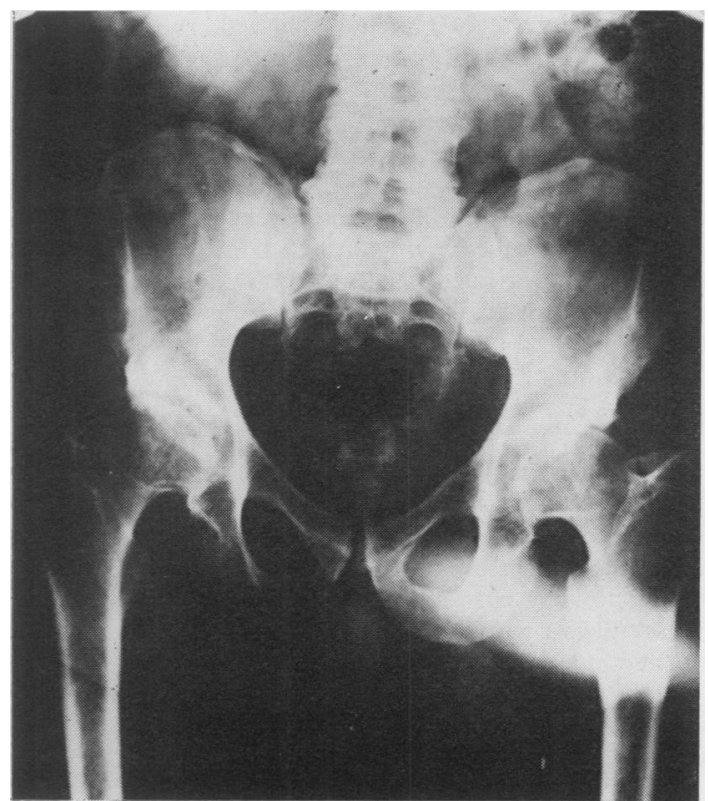

Fig. 7. Pelvis and hip $x$-ray of V.41 aged 37, showing narrow pelvis and dysplastic changes in hips.
He had been very active in sports, including football, basketball, and baseball, and was currently taking part in motor racing and scuba diving. He worked as an aircraft engineer, travelling all over the world for his company as an instructor. His small stature was of advantage in allowing him to get into inaccessible parts of aircraft including the inside of jet engines. He had never had any serious illness and had no complaints about his health; he had never experienced any discomfort or stiffness in spine or joints.

On examination, he was $57 \frac{1}{2}$ inches in height and showed the characteristic appearance (Fig. 8) though perhaps in a less marked degree than the other affected men. His chest was barrel shaped and the abdomen was very short. The neck was short, but movements were full and free, as they were throughout the spine, including the lumbar spine. There was full painless movement of the hips and all other joints. Radiology of the spine showed the characteristic changes (Fig. 9), and there were quite marked dysplastic changes in the hip joints (Fig. 10), but with negligible secondary osteoarthritic changes.

V.43 (M.P.) younger sister of V.41 and V.42, is a member of a Roman Catholic teaching order. Although she had a history of painful joints, no physical abnormalities were found when she was examined by us when

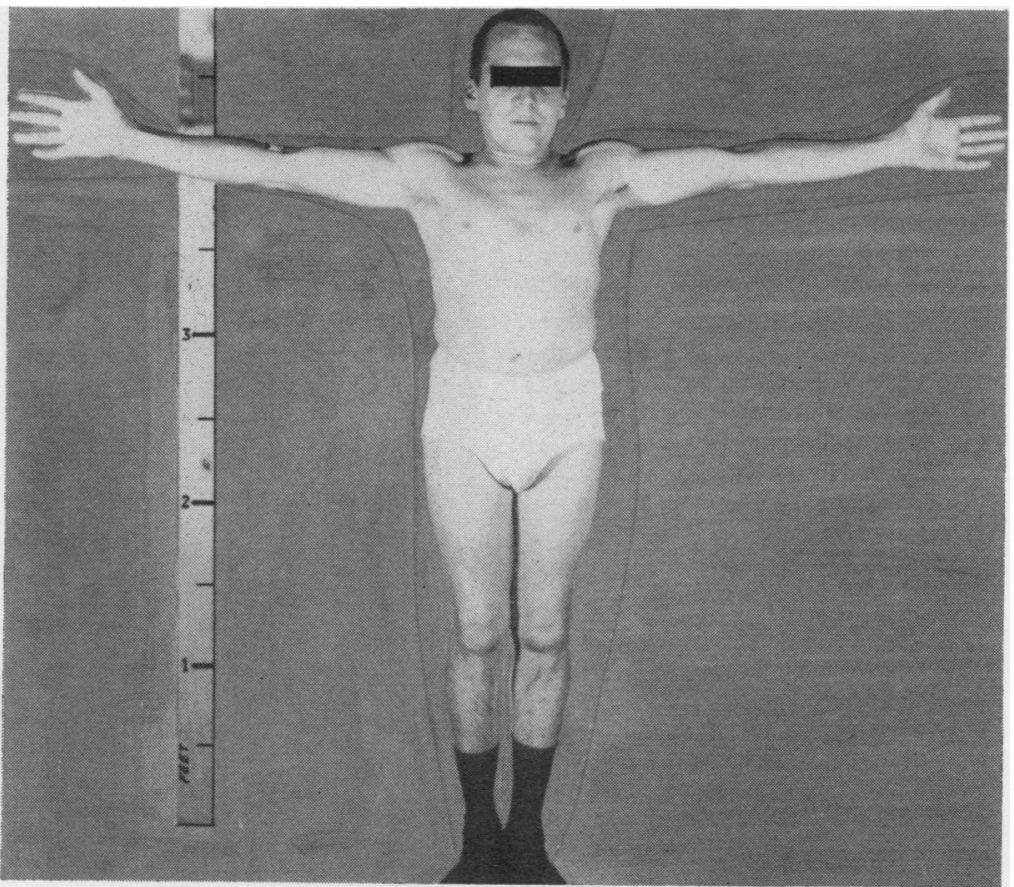

Fig. 8. An affected male (V.42) aged 33, showing shortening of trunk and neck with relatively long limbs. 


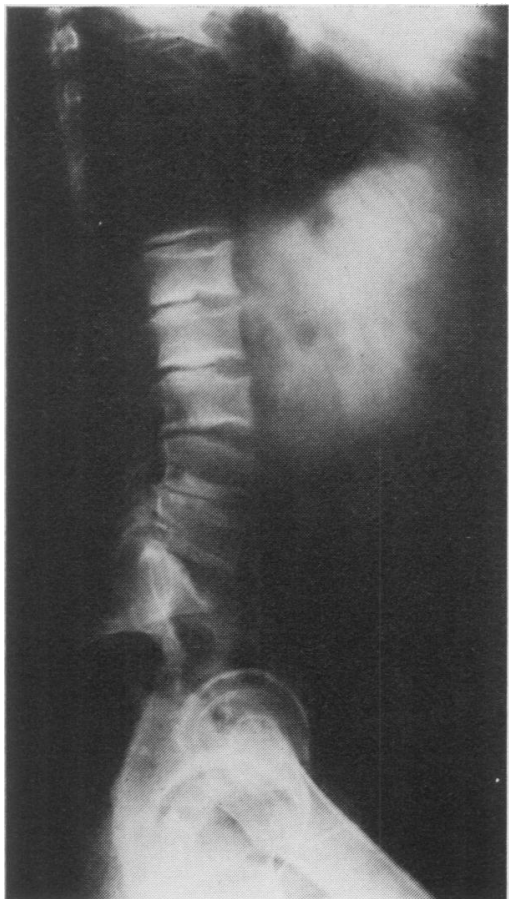

Fig. 9. Lateral $x$-ray of lumbar spine in an affected male (V.42) aged 33, showing the characteristic vertebral changes (as in Figs. 5, 6, and 12) but an absence of abnormal calcification. she was aged 30. Radiology of the spine, pelvis, and hips was normal.

V.45 (C.B.) was delivered by Caesarean section at 7 months. Infancy and childhood were normal, but he was stated to have 'stopped growing' at 8 . He graduated from high school and despite the disability of congenital deafness has worked steadily as a compositor. He is also an enthusiastic semi-professional wrestler. On examination, aged 26 , he was a small man (height 54 inches) with short trunk and slightly rolling gait. The chest appeared barrel-shaped, bulging upwards and outwards in the upper part. The neck was very short. Lumbar lordosis was exaggerated, but there was no dorsal kyphosis (Fig. 11). There was slight limitation on movement of the hip joints, particularly of rotation on the right. Other joints moved freely although the right ankle clicked. There was a minor degree of syndactyly of the second and third toes on the right. Radiology showed characteristic changes of the lower dorsal and lumbar vertebrae (Fig. 12) with resulting loss of the normal dorsal kyphosis. There were also dystrophic changes of the femoral heads and necks with flattening of the superior portions of the femoral heads and short femoral necks similar to the changes shown in V.41, his cousin. Radiology of the right foot and ankle showed dysplastic changes involving the astragalus, with flattening of the superior portions of the astragalus and relatively normal subastragular joint.

Other Cases. Two of the daughters of an affected male or of a known female carrier had male children.

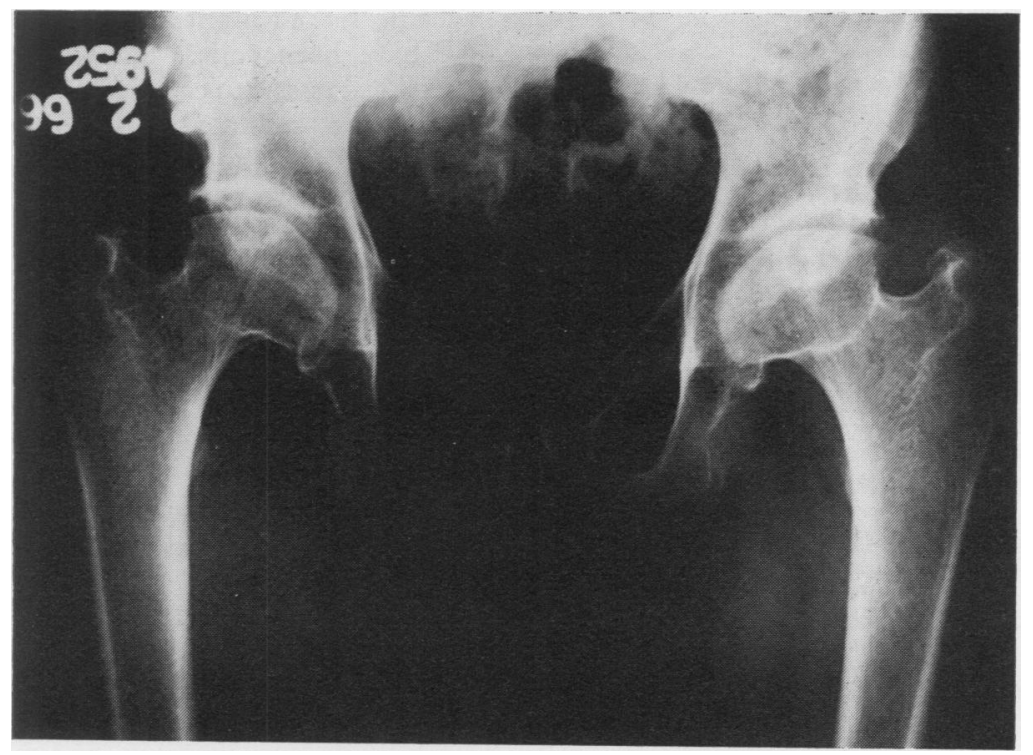

FIG. 10. V.42 aged 33: $x$-ray of pelvis and hips showing narrow pelvis and dysplastic changes in hip joints. 


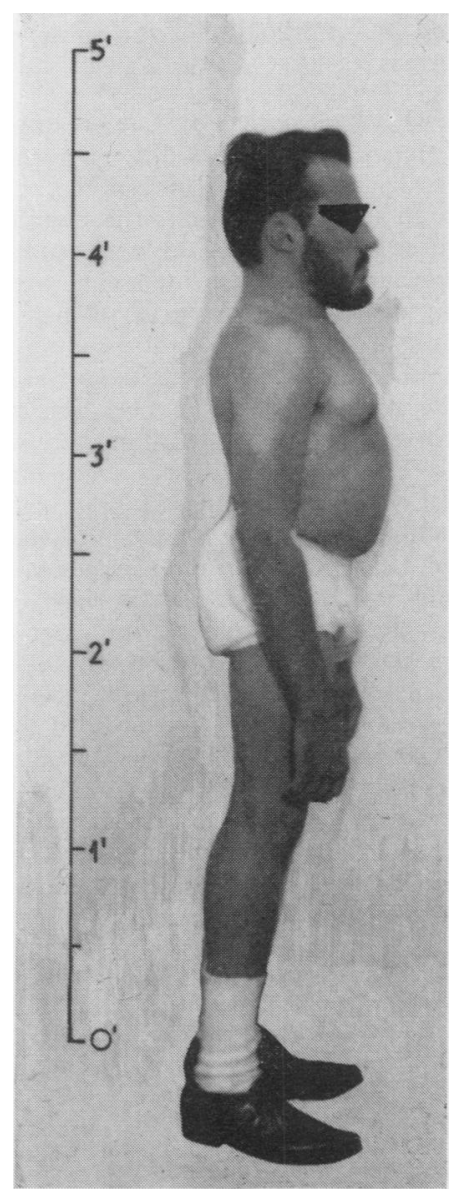

FIG. 11. Side view of an affected male (V.45) aged 27, showing short stature, relatively long limbs, and exaggerated lumbar lordosis.

V.10 had two boys; the eldest (VI.7) aged 15, was already 62 inches in height and not affected, and his 6-year-old brother (VI.8) was $47 \frac{1}{2}$ inches and probably not affected, though $x$-rays were not available. V.40 had three sons; VI.37 and VI.38 were both found on radiology to have normal spines. Although VI.38, when first examined at 13 was 3 inches shorter than his 10-year-old brother (VI.39) by the age of 17 he was $62 \frac{1}{2}$ inches in height. VI.39 was normal to clinical examination, but $x$-rays were not available.

\section{Results and Discussion}

Linkage Study. The informative part of the pedigree includes generations IV (in which three affected males and three carrier females were tested) and generations V and VI. All Xga data are included in Table $I$. Extensive other blood group data, which are not reported here, were compatible with the stated family relationships.

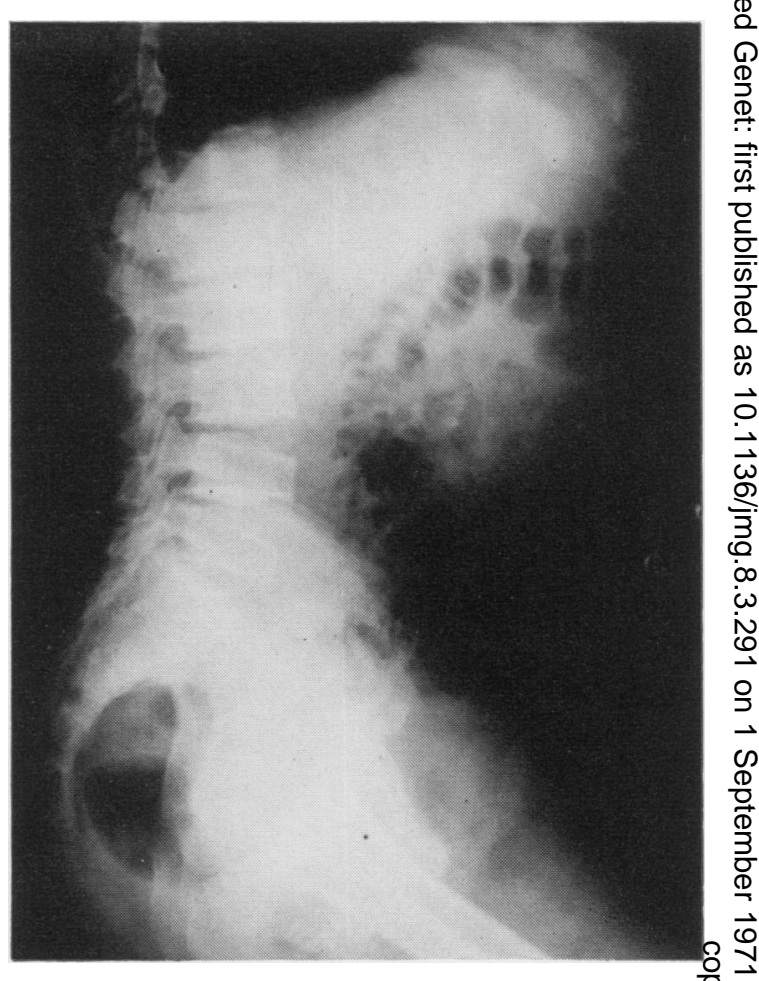

Fig. 12. Lumbar spine $x$-ray of the patient shown in Fig. 11 (V.45) Note the similarity to the $x$-rays of his cousin (Fig. 5) and the absence of abnormal calcification at the age of 27 .

Results of colour blindness testing are also given in Table I. Two affected males, IV.6 and IV.18, may have been colour blind, but had such poor general vision due to cataracts that they could not be scored with confidence. Two unaffected males, VI.37 and VI.38 showed protan colour blindness.

Linkage between the $\mathrm{Xg}$ blood group locus and the $S D T$ locus was estimated from lod scores calculated by an IBM 7094 computer, using the program of Renwick and Schulze (1961). For transformation of $\theta$ values to $w$, the method of Carter and Falconer (1951) has been used, following Renwick and Schulze (1964). The prior probabilities are taken to be proportional to $L-w$, where $L$ is the map length of the differential part of the $\mathrm{X}$ chromosome, assumed here to be 2 morgans. From these values final relative probabilities have been calculated (Table II) and plotted against $w$ (Fig. 13). From this plot the most probable map distance between $S D T$ and $X g$ is about 0.40 morgans, but the $95 \%$ probability region ( 0.14 to 1.60 morgans) associated with this map interval exceeds half the assumed map length of the chromosome, and the estimate must, therefore, be regarded as highly provisional. 
Similar calculations have been carried out for the loci are set out in Table II; but the data at present colour blindness data, and lod scores, antilods, and final relative probabilities for the $S D T$ and protan

available do not allow a useful estimate.

Recent studies on mapping the human X-chromo-

TABLE I

\begin{tabular}{|c|c|c|c|c|c|c|c|}
\hline $\begin{array}{l}\text { Pedigree } \\
\text { Number* }\end{array}$ & Sex & $\begin{array}{c}\text { Date of } \\
\text { Birth }\end{array}$ & Age† & $\begin{array}{l}\text { Height } \\
\text { (in.) }\end{array}$ & Clinical Findings & $\begin{array}{l}\text { Colour } \\
\text { Vision }\end{array}$ & $\underset{\text { Type }}{\mathrm{Xg}^{\mathrm{a}}}$ \\
\hline III.5 & $M$ & 1873 & d. 71 & 58 & Affected (Jacobsen, 1939) (see text) & nt & nt \\
\hline $\begin{array}{l}\text { IV.6 } \\
\text { IV.7 } \\
\text { IV. } 9 \\
\text { IV.11 } \\
\text { IV.12 } \\
\text { IV.13 } \\
\text { IV.14 } \\
\text { IV.15 } \\
\text { IV.16 } \\
\text { IV.18 } \\
\text { IV.20 } \\
\text { IV.23 } \\
\text { IV.24 } \\
\text { IV.29 } \\
\text { IV.31 } \\
\text { IV. } 32\end{array}$ & $\begin{array}{l}M \\
\mathbf{F} \\
\mathbf{F} \\
\mathbf{M} \\
\mathrm{F} \\
\mathrm{M} \\
\mathrm{F} \\
\mathrm{M} \\
\mathrm{F} \\
\mathbf{M} \\
\mathrm{M} \\
\mathrm{M} \\
\mathrm{F} \\
\mathrm{F} \\
\mathrm{F} \\
\mathbf{M}\end{array}$ & $\begin{array}{c}1898 \\
\text { nt } \\
\text { nt } \\
\text { nt } \\
1898 \\
1899 \\
1901 \\
1903 \\
1923 \\
1905 \\
1909 \\
1902 \\
1900 \\
1908 \\
1910 \\
1912\end{array}$ & $\begin{array}{l}67 \\
\text { nt } \\
\text { nt } \\
\text { nt } \\
67 \\
68 \\
64 \\
63 \\
42 \\
60 \\
56 \\
63 \\
65 \\
58 \\
56 \\
54\end{array}$ & $\begin{array}{l}55 \\
\text { nt } \\
\text { nt } \\
n t \\
n t \\
\text { nt } \\
\text { nt } \\
55 \\
\text { nt } \\
55 \\
\text { nt } \\
\text { nt } \\
\text { nt } \\
62 \\
61 \frac{1}{2} \\
\text { nt }\end{array}$ & $\begin{array}{l}\text { Affected (see text) } \\
\text { Not affected } \\
\text { Affected (see text) } \\
\text { Affected (see text) } \\
\text { Carrier (see text) } \\
\text { Carrier (see text) } \\
\text { Carrier (see text) }\end{array}$ & $\begin{array}{c}\text { nt } \\
\text { nt } \\
\text { nt } \\
\text { nt } \\
\text { nt } \\
\text { nt } \\
\text { nt } \\
\text { nt } \\
\text { nt } \\
\text { nt } \\
\text { nt } \\
\text { nt } \\
\text { Normal } \\
\text { nt } \\
\text { Normal } \\
\text { nt }\end{array}$ & $\begin{array}{l}\mathbf{X g}(\mathbf{a}-) \\
\mathbf{X} \mathbf{g}(\mathbf{a}+) \\
\mathbf{X g}(\mathbf{a}+) \\
\mathbf{X} \mathbf{g}(\mathbf{a}-) \\
\mathbf{X} \mathbf{g}(\mathbf{a}+) \\
\mathbf{X g}(\mathbf{a}+) \\
\mathbf{X g}(\mathbf{a}-) \\
\mathbf{X} \mathbf{g}(\mathbf{a}-) \\
\mathbf{X g}(\mathbf{a}+) \\
\mathbf{X} \mathbf{g}(\mathbf{a}+) \\
\mathbf{X} \mathbf{g}(\mathbf{a}+) \\
\mathbf{X} \mathbf{g}(\mathbf{a}-) \\
\mathbf{X} \mathbf{g}(\mathbf{a}+) \\
\mathbf{X} \mathbf{g}(\mathbf{a}-) \\
\mathbf{X} \mathbf{g}(\mathbf{a}+) \\
\mathbf{X} \mathbf{g}(\mathbf{a}+)\end{array}$ \\
\hline $\begin{array}{l}\text { V.10 } \\
V .11 \\
V .15 \\
\text { V.17 } \\
\text { V.18 } \\
V .21 \\
\text { V.22 } \\
\text { V.23 } \\
\text { V.37 } \\
\text { V.39 } \\
V .40 \\
V .41 \\
\text { V.42 } \\
\text { V.43 } \\
\text { V.45 } \\
\text { V.46 }\end{array}$ & $\begin{array}{l}\mathbf{F} \\
\mathbf{F} \\
\mathbf{M} \\
\mathbf{F} \\
\mathbf{F} \\
\mathbf{F} \\
\mathbf{M} \\
\mathbf{M} \\
\mathbf{M} \\
\mathbf{F} \\
\mathbf{M} \\
\mathbf{M} \\
\mathbf{F} \\
\mathbf{M} \\
\mathbf{F}\end{array}$ & $\begin{array}{c}1927 \\
\mathrm{nt} \\
\mathrm{nt} \\
1925 \\
1917 \\
1944 \\
1946 \\
1948 \\
1921 \\
1920 \\
1926 \\
1929 \\
1933 \\
1935 \\
1938 \\
1940\end{array}$ & $\begin{array}{l}38 \\
\text { nt } \\
\text { nt } \\
41 \\
49 \\
22 \\
20 \\
18 \\
44 \\
45 \\
38 \\
37 \\
33 \\
30 \\
26 \\
24\end{array}$ & $\begin{array}{l}\text { nt } \\
\text { nt } \\
\text { nt } \\
n t \\
\text { nt } \\
\text { nt } \\
\text { nt } \\
\text { nt } \\
52 \frac{1}{2} \\
\text { nt } \\
62 \frac{1}{2} \\
\text { nt } \\
57 \frac{1}{2} \\
\text { nt } \\
54 \\
\text { nt }\end{array}$ & $\begin{array}{l}\text { Healthy; no arthritis } \\
\text { Not examined } \\
\text { Normal } \\
\text { Normal } \\
\text { Normal } \\
\text { Affected (see text) } \\
\text { Affected (see text) } \\
\text { Affected (see text) } \\
\text { See text } \\
\text { Affected; also congenital deafness (see text) } \\
\text { nt (congenital deafness) }\end{array}$ & $\begin{array}{l}\text { nt } \\
\text { nt } \\
\text { nt } \\
\text { nt } \\
\text { nt } \\
\text { nt } \\
\text { nt } \\
\text { nt } \\
\text { nt } \\
\text { Normal } \\
\text { Normal } \\
\text { nt } \\
\text { Normal } \\
\text { Normal } \\
\text { Normal } \\
\text { nt }\end{array}$ & 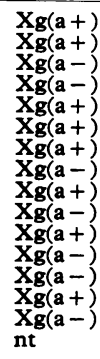 \\
\hline $\begin{array}{l}\text { VI. } 6 \\
\text { VI. } \\
\text { VI. } \\
\text { VI.9 } \\
\text { VI. } 32 \\
\text { VI. } 33 \\
\text { VI. } 34 \\
\text { VI. } 35 \\
\text { VI. } 37 \\
\text { VI. } 38 \\
\text { VI. } 39\end{array}$ & $\begin{array}{l}\mathbf{F} \\
\mathbf{M} \\
\mathbf{M} \\
\mathbf{F} \\
\mathbf{M} \\
\mathbf{F} \\
\mathbf{M} \\
\mathbf{F} \\
\mathbf{M} \\
\mathbf{M} \\
\mathbf{M}\end{array}$ & $\begin{array}{l}1948 \\
1950 \\
1959 \\
1961 \\
1949 \\
1948 \\
1953 \\
1945 \\
1948 \\
1952 \\
1954\end{array}$ & $\begin{array}{r}17 \\
15 \\
6 \\
4 \\
16 \\
15 \\
12 \\
19 \\
15 \\
13 \\
10\end{array}$ & $\begin{array}{l}\mathrm{nt} \\
62 \\
47 \frac{1}{2} \\
42 \\
63 \\
60 \\
61 \\
66 \\
66 \frac{1}{2} \\
55 \frac{1}{2} \\
58 \frac{1}{2}\end{array}$ & $\begin{array}{l}\text { Congenital retinal degeneration } \\
\text { Normal examination and spine } x \text {-rays } \\
\text { Normal examination and spine } x \text {-rays } \\
\text { Normal examination }\end{array}$ & $\begin{array}{c}\text { nt } \\
\text { nt } \\
\text { nt } \\
\text { nt } \\
\text { Normal } \\
\text { Normal } \\
\text { Normal } \\
\text { nt } \\
\text { Protan } \\
\text { Protan } \\
\text { Normal }\end{array}$ & 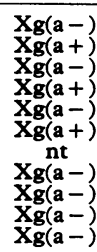 \\
\hline
\end{tabular}

* Pedigree numbers refer to pedigree in Figure 1. $\mathrm{d}=$ dead; $\mathrm{nt}=$ not tested, or not known.

TABLE II

LOD SCORES FOR LINKAGE RELATIONSHIP BETWEEN $X g$ AND SDT, AND PROTAN AND SDT LOCI

\begin{tabular}{|c|c|c|c|c|c|c|c|c|c|c|c|c|c|}
\hline \multirow{2}{*}{ Loci } & \multirow[b]{2}{*}{$\begin{array}{l}0 \\
0\end{array}$} & \multirow[b]{2}{*}{$\begin{array}{l}0.05 \\
0.05\end{array}$} & \multirow[b]{2}{*}{$\begin{array}{l}0 \cdot 10 \\
0 \cdot 10 \\
\end{array}$} & \multicolumn{4}{|c|}{$\begin{array}{c}\text { Map interval (w morgans) by Carter } \\
\text { and Falconer's formula }\end{array}$} & \multirow[b]{2}{*}{$\begin{array}{l}0.37 \\
0.35\end{array}$} & \multirow[b]{2}{*}{$\begin{array}{l}0.44 \\
0.40\end{array}$} & \multirow[b]{2}{*}{$\begin{array}{l}0.55 \\
0.45\end{array}$} & \multirow[b]{2}{*}{$\begin{array}{l}0.69 \\
0.482\end{array}$} & \multirow[b]{2}{*}{$\begin{array}{l}0.95 \\
0.498\end{array}$} & \multirow[b]{2}{*}{$\begin{array}{l}2.00 \\
0.50\end{array}$} \\
\hline & & & & $\begin{array}{c}0.15 \\
0.15\end{array}$ & $\begin{array}{c}0.20 \\
0.20\end{array}$ & $\begin{array}{c}0.25 \\
\text { fraction, } \theta \\
0.25\end{array}$ & $\begin{array}{l}0.31 \\
0.30\end{array}$ & & & & & & \\
\hline 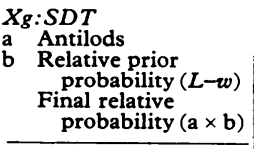 & $\begin{array}{l}-\infty \\
0 \\
2 \cdot 00 \\
0\end{array}$ & $\begin{array}{c}-2.198 \\
0.006 \\
1.95 \\
0.012 \\
\end{array}$ & $\begin{array}{c}-1.146 \\
0.071 \\
1.90 \\
0.136 \\
\end{array}$ & $\begin{array}{c}-0.605 \\
0.248 \\
1.85 \\
0.459\end{array}$ & $\begin{array}{c}-0.280 \\
0.525 \\
1.80 \\
0.945 \\
\end{array}$ & $\begin{array}{c}-0.077 \\
0.838 \\
1.75 \\
1.463\end{array}$ & \begin{tabular}{l|}
0.043 \\
1.105 \\
1.69 \\
1.87 \\
\end{tabular} & $\begin{array}{l}0.102 \\
1.265 \\
1.63 \\
2.06\end{array}$ & $\begin{array}{l}0.111 \\
1.291 \\
1.56 \\
2.01\end{array}$ & $\begin{array}{l}0.076 \\
1.191 \\
1.45 \\
1.73 \\
\end{array}$ & $\begin{array}{l}0.026 \\
1.062 \\
1.31 \\
1.391\end{array}$ & $\begin{array}{l}0.003 \\
1.007 \\
1.050 \\
1.057\end{array}$ & $\begin{array}{l}0 \\
1 \\
0 \\
0\end{array}$ \\
\hline $\begin{array}{l}S D T: \text { protan } \\
\text { c Antilods } \\
\text { d } \\
\text { Relative prior } \\
\text { probability }(L-w) \\
\text { Final relative } \\
\text { probability }(\mathrm{c} \times \mathrm{d})\end{array}$ & $\begin{array}{l}-\infty \\
0 \\
2 \cdot 00 \\
0\end{array}$ & $\begin{array}{r}-2.4 \\
0.00 \\
1.95 \\
0.00\end{array}$ & $\begin{array}{c}-0.754 \\
0.176 \\
1.90 \\
0.335\end{array}$ & $\begin{array}{c}-0.549 \\
0.282 \\
1.85 \\
0.522\end{array}$ & $\begin{array}{c}-0.400 \\
0.403 \\
1.80 \\
0.724\end{array}$ & $\begin{array}{c}-0.270 \\
0.538 \\
1.75 \\
0.939\end{array}$ & $\begin{array}{c}-0.160 \\
0.692 \\
1.69 \\
1.171\end{array}$ & $\begin{array}{c}-0.076 \\
0.840 \\
1.63 \\
1.370\end{array}$ & $\begin{array}{c}-0.021 \\
0.953 \\
1.56 \\
1.483\end{array}$ & $\begin{array}{l}0.004 \\
1.01 \\
1.45 \\
1.462\end{array}$ & & & \\
\hline
\end{tabular}




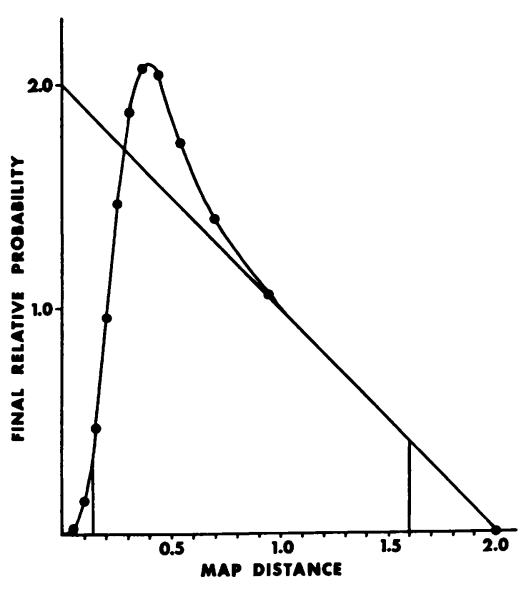

FIG. 13. Final relative probability plotted against map distance $w$ in morgans for $\mathrm{Xg}$ and $S D T$. The maximum is at 0.395 morgans with $95 \%$ probability limits from 0.14 to 1.60 morgans. (See text and Table II.)

some, especially in relation to the $X g$ locus, have been summarized by Sanger and Race (1970). The relative positions of at least 6 loci are known, although as these authors have ruefully pointed out, definitive results have been harder to obtain than once seemed possible.

Rare X-linked traits provide only limited information. In the present study, $S D T$ like several others, enters a limbo from which it may eventually emerge into more exactly measurable linkage distance of a marker such as $X g$. The addition of linkage data from other pedigrees would be helpful. It is unfortunate that the data on colour blindness in this family did not turn out to be more useful.

Clinical Aspects. The clinical features of SDT have been described by previous authors mentioned in the introduction, particularly Maroteaux et al (1957), and the radiological findings have been set out by Langer (1964). In addition to the references already cited, two brothers reported by Halberstaedter (1943) probably had SDT, and a single case was reported in detail by Specht (1968). The patients of various ages reported here, sometimes re-examined after a long interval, give a picture of the natural history of the disorder. Although symptoms are rarely evident before 7-10 years of age, radiological changes certainly exist earlier in childhood, as early as $3 \frac{1}{2}$ years as Jacobsen (1939) has reported (V.42 in the present series), and would allow early diagnosis. The absence of such changes in VI.37 and VI.38 at ages 10 and 13 allowed us to reassure their parents with reasonable confidence.
The characteristic clinical features, mentioned above, are shortness of the trunk, with a short neck. Kyphosis is usual but not invariable and there may instead be undue straightness of the spine (Maroteaux et al, 1957), as seen in the propositus, V.37. The vertebral changes, best seen in lateral $x$-rays of the lower dorsal and lumbar spine, are pathognomonic, as illustrated by Langer (1964) and here in Figures 5 and 12. The shortness and broadness of the thorax is usually striking, particularly when seen in an $x$-ray of the whole body in which it tends to dwarf the narrow pelvis (Fig. 3). The hip joints of all our patients are severely dysplastic and this may be an invariable feature. Other bony changes are inconstant, but include anomalies of the shoulder joints associated with deformity of the lower end of the radius (Maroteaux et al, 1957), and minor degrees of flattening of articular surfaces of all large joints including shoulders, knees, and ankles (Langer, 1964), as in V.45.

Although short stature and disproportion are evident before puberty, severe symptoms in childhood are rare, and the incapacitating back pain in the propositus at 15 is unusual. Generally, there is little disability until secondary arthritic changes appear in the late thirties or early forties. Thus V.42 aged 33, and showing marked radiological changes was conscious of no symptoms and no limitation of activity. His elder brother (V.41) whose spine already showed abnormal intervertebral calcification (Fig. 6) at 37, was not known to have symptoms although we did not see him. Yet their cousin (V.37) aged 44 was already experiencing stiffness and occasional pain. In the fifties and sixties arthritis becomes bad enough to prevent work and seriously limits activity. It may be suspected that the kyphosis and abnormal rib position impair chest movement and predispose to the development of emphysema and chronic bronchitis, but this has not been documented. Our propositus, at 44, was complaining of shortness of breath, and the older patients might well have been breathless if their activities had not been so much limited by their arthritis.

Intelligence is normal and all the patients we have met were brisk and lively men who had largely triumphed over their limitations. V.45, who was also congenitally deaf, had a skilled job as a foreignlanguage compositor and was also a keen semiprofessional wrestler. There is no evidence of visceral or neuromuscular involvement, but to our knowledge, no necropsy on an SDT patient has been reported.

Total urinary mucopolysaccharide excretion is not increased and metachromatic staining is not seen in 
cultured fibroblasts from SDT patients, although the hexose content of the cultured cells is increased above that of normal fibroblasts, in common with fibroblasts in other forms of spondyloepiphyseal dysplasia (Danes and Grossman, 1969). The significance of this observation is uncertain, and as yet no specific metabolic abnormality has been described.

Do heterozygous female carriers show any changes? It has been suggested that they may have a high incidence of arthritis. We were able to examine three sisters who are obligatory carriers (IV.24, 29, and 31). Their stature was normal and while one developed rheumatoid arthritis in her thirties and was found to be partially disabled by a secondary osteoarthritis, especially of the hips, at 65, the other two, in their late fifties, had no important joint complaints and $x$-rays of their spines and hip joints were normal.

\section{Summary}

Jacobsen's pedigree of X-linked spondyloepiphyseal dysplasia tarda was re-investigated, and 7 affected men, aged from 26 to 67 years were studied. Radiological changes may be evident in early childhood, short stature and disproportion are usually recognized before puberty, and the bony changes lead to secondary osteoarthritis which becomes troublesome in the forties and disabling by the sixties. Heterozygous female carriers show no consistent changes. No specific metabolic abnormality has yet been described.

Linkage studies in this family using the $X g$ blood group and colour blindness do not demonstrate any close linkage; the maximum probability estimate for the map interval $S D T$ to $X g$ is 0.40 morgans with wide probability limits.

We are grateful to Dr Victor McKusick for putting us in touch with the family and for his continued help; to Dr James Renwick for the analysis of linkage data and for his valuable advice; to Dr Amos Cahan for the original gift of anti-Xg ${ }^{\mathbf{a}}$ serum; and to Dr Robert Weilbacher and Dr Peter H. Pinkerton who collaborated in visiting the family in North Carolina. We also thank the following physicians for their cooperation: Dr Mathew Burke (Buffalo, New York), Dr A. L. Cloninger (Hamlet, N. Carolina), Dr W. H. Phifer (Monroe, N. Carolina), Dr Chesley R. Houske (Torrance, California), Dr Herbert Dozoretz (Phoenix, Arizona), Dr D. W. Davis (Wadesboro, N. Carolina), Dr William C. Irvin, (Norfold, Virginia), and especially Dr A. Wilmot Jacubsen of Buffalo, New York, for his interest and for access to the early $x$-rays of his patient. For other $x$ rays we are indebted to Dr Culver and the $x$-ray Department of the Buffalo General Hospital.
Figures $2,5 b$, and 11 are reprinted from the First Symposium on the Clinical Delineation of Birth Defects, in Birth Defects: Original Article Series (1969) by kind permission of the Editors and the National FoundationMarch of Dimes, New York.

These studies were supported by USPHS grants, nos. AM-05581 from the National Institute of Arthritis and Metabolic Diseases, and HE-05351 and HE-05688 from the National Heart and Lung Institute, and by grants from the Arthritis Foundation, the National Foundation - March of Dimes, and the New York State Birth Defects Institute (Contract no. C-40084-BD1). Calculations of the lod scores were supported by grants from the Hartford Foundation and the National Institutes of Health (GH-10189) to Dr V. A. McKusick (Baltimore). They were carried out in the Johns Hopkins University at its Homewood and Medical Computing Centers, supported respectively by educational contributions from the IBM Corporation and by grant FR-00004 from the US National Institutes of Health.

\section{REFERENCES}

Bannerman, R. M. (1969). X-linked spondyloepiphyseal dysplasia tarda (SDT). Birth Defects: Original Article Series, V, 4, pp. 4851. The National Foundation-March of Dimes, New York.

Bannerman, R. M., Ingall, G. B., and Mohn, J. F. (1966a). Xlinked spondyloepiphyseal dysplasia tarda: clinical and linkage data (Abstr.). Presented at III International Congress of Human Genetics, Chicago. Abstracts of contributed papers, no. 16, p. 5.

Bannerman, R. M., Ingall, G. B., and Mohn, J. F. (1966b). Spondyloepiphyseal dysplasia tarda: clinical and linkage studies. (Abstr.) Clinical Research, 14, 308.

Barber, H. S. (1960). An unusual form of familial osteodystrophy. Lancet, 1, 1220-1221.

Carter, T. C. and Falconer, D. S. (1951). Stocks for detecting linkage in the mouse and the theory of their design. Fournal of Genetics, 50, 307-323.

Danes, B. S. and Grossman, H. (1969). Bone dysplasias, including Morquio's syndrome, studied in skin fibroblast cultures. American fournal of Medicine, 47, 708-720.

Halberstaedter, M. (1943). Familial vertebral dystrophy. Case Reports. British fournal of Radiology, 16, 121-124.

Hobaek, A. (1961). Problems of Hereditary Chondrodysplasias. Norwegian Universities Press, Oslo.

Jacobsen, A. W. (1939). Hereditary osteochondro-dystrophia deformans. A family with twenty members affected in five generations. Fournal of the American Medical Association, 113, 121-124.

Langer, L. O., Jr. (1964). Spondyloepiphyseal dysplasia tarda. Hereditary chondrodysplasia with characteristic vertebral configuration in the adult. Radiology, 82, 833-839.

Maroteaux, P., Lamy, M., and Bernard, J. (1957). La dysplasie spondylo-épiphysaire tardive, description clinique et radiologique. Presse Médicale, 65, 1205-1208.

Nilsonne, H. (1927). Eigentümliche Wirbelkörperveränderungen mit familiären Auftreten. Acta Chirurgica Scandinavica, 62, 550-554.

Renwick, J. H. and Schulze, J. (1961). A computer programme for the processing of linkage data from large pedigrees. Second International Conference of Human Genetics (abstracts), p. E145. Excerpta Medica, Amsterdam. International Congress Series 32.

Renwick, J. H. and Schulze, J. (1964). An analysis of some data on linkage between $\mathbf{X g}$ and colorblindness in man. American Fournal of Human Genetics, 16, 410-418.

Sanger, R. and Race, R. R. (1970). Towards mapping the X chromosome. In Modern Trends in Human Genetics, I, 241-266, edited by A. E. H. Emery. Butterworth, London.

Specht, E. E. (1968). Spondyloepiphyseal dysplasia tarda. A case report. Clinical Orthopaedics (Philadelphia), 60, 159-162.

Volhard, E. and Drigalski, W. von (1937). Über eine eigenartige familiäre Entwicklungsstörung des Rumpfskeletts. Zentrablatt für innere Medizin, 58, 243-252. 